\title{
Contemplating the feasibility of vermiculate blended chitosan for heavy metal removal from simulated industrial wastewater
}

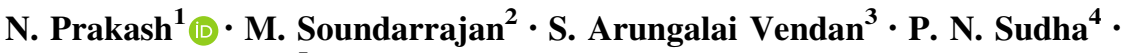 \\ N. G. Renganathan ${ }^{5}$
}

Received: 10 November 2013/Accepted: 24 November 2015/Published online: 14 December 2015

(C) The Author(s) 2015. This article is published with open access at Springerlink.com

\begin{abstract}
Wastewater contaminated by heavy metals pose great challenges as they are non biodegradable, toxic and carcinogenic to the soil and aquifers. Vermiculite blended with chitosan have been used to remove $\mathrm{Cr}(\mathrm{VI})$ and $\mathrm{Cd}(\mathrm{II})$ from the industrial wastewater. The results indicate that the vermiculite blended with chitosan adsorb $\mathrm{Cr}(\mathrm{VI})$ and $\mathrm{Cd}(\mathrm{II})$ from industrial waste water. Batch adsorption experiments were performed as a function of $\mathrm{pH}$ 5.0 and 5.5 respectively for chromium and cadmium. The adsorption rate was observed to be 72 and $71 \%$ of chromium and cadmium respectively. The initial optimum contact time for $\mathrm{Cr}(\mathrm{VI})$ was $300 \mathrm{~min}$ with $59.2 \%$ adsorption and $300 \mathrm{~min}$ for $\mathrm{Cd}(\mathrm{II})$ with $71.5 \%$ adsorption. Whereas, at 4-6 there is saturation, increasing the solid to liquid ratio for chitosan biopolymers increases the number of active sites available for adsorption. The optimum $\mathrm{pH}$ required for maximum adsorption was found to be 5.0 and 5.5 for chromium and cadmium respectively. The experimental equilibrium adsorption data were fitted using Langmuir and Freundlich equations. It was observed that adsorption kinetics of both the metal ions on vermiculite
\end{abstract}

N. Prakash

prakash.nagapillai@gmail.com

1 Department of Chemistry, Thangavelu Engineering College, Chennai 600 097, India

2 Department of Chemistry, Valliammai Engineering College, Kattankulathur 603 203, India

3 School of Electrical Engineering, VIT University, Vellore, India

4 Department of Chemistry, D.K.M. College for Women, Vellore 632 001, India

5 Department of Chemistry, Vel Tech University, Avadi, Chennai, India blended chitosan is well be analyzed with pseudo-secondorder model. The negative free energy change of adsorption indicates that the process was spontaneous and vermiculite blended chitosan was a favourable adsorbent for both the metals.

Keywords Chromium(VI) - Cadmium(II) - Chitosan mixed vermiculite $\cdot$ Adsorption isotherms $\cdot$ Kinetics

\section{Introduction}

Chromium and cadmium are highly toxic heavy metals and these have to be removed from the water sources. These metals are from various industrial effluents such as tanneries, electroplating and paints. The chromium toxicity is mainly induced from its hexavalent form, $\mathrm{Cr}(\mathrm{VI})$ which is readily soluble in water. Its concentration should not exceed $0.05 \mathrm{mg} \mathrm{l}^{-1}$ in drinking water and become more toxic with potential carcinogenic effects (Baird and Cann 2005). Cadmium belongs to the hazardous metal group. It is fairly mobile in soil and is primarily present as an organically bound, exchangeable and water soluble species (Holm et al. 1995; Chlopecka 1996). The removal of cadmium from the wastewater by various techniques such as chemical precipitation, electro deposition, electro coagulation process, ion exchange and emulsion liquid membrane (Vasudevan et al. 2011; Elkady et al. 2011; Ahmad et al. 2012). These techniques are expensive and ineffective at low concentration of metal ions. Adsorption method is reported to be a favourable method owing to its low cost and high efficiency for high and low concentration of metal ions (Ngah and Hanafiah 2008).

Novel adsorbents prepared from orange peel and $\mathrm{Fe}_{2} \mathrm{O}_{3}$ nano particles have been used (Gupta et al. 2012) to 
remove cadmium from aqueous solutions. The removal of cadmium from the electroplating industry effluent is reported and is shown to have desorption and reusability without loss of efficiency. Material from the low cost fertilizer industry viz., carbon slurry, has been chemically treated, activated and used as adsorbent to remove hexavalent chromium from aqueous solutions (Gupta et al. 2010) and the kinetics of adsorption follows pseudo second order rate equation based on batch experiments. The removal of lead and chromium from aqueous solutions, has been reported using inexpensive red mud, an aluminium industry waste and bagasse fly ash. The blast furnace waste generated in steel plants has been used for the removal of lead and chromium (Srivastava et al. 1997) and the authors concluded that the efficiency is higher for lead than that of chromium.

Low cost adsorbents have been investigated from agricultural and fishery wastes such as rice hull and saw dust (Asadi et al. 2008), peanut husk (Li et al. 2007), pumpkin waste (Horsfall et al. 2006), Nipah palm (Nypa fruticans Wurmb), shoot biomass (Wankasi et al. 2006), prawn shell (Chu 2002), crab shell (Dahiya et al. 2008), chitin (Jayakumar et al. 2009) and chitosan (Tao et al. 2009) to remove metal ions from wastewater. Chitosan biopolymer (Kumari et al. 2009; ShahinHydari et al. 2012; Prakash et al. 2011) and vermiculite clay (Malandrino et al. 2006; Maria Rosaria Panuccio et al. 2009) are being explored recently for the removal of heavy metals from wastewater.

Chitosan, poly $(\beta(1-4)$-2-amino-2-deoxy-D-glucose is obtained from partial $N$-deacetylation of chitin with a strong alkali solution such as sodium hydroxide. It is characterized by a high content of nitrogen, present as amine groups capable of binding the metal ion through several mechanisms, including chemical interactions, such as chelation, electrostatic interactions (or) ion-exchange. The interaction depends ( $\mathrm{Ng}$ et al. 2003; Dzul Erosa et al. 2001) on the metal ions and initial $\mathrm{pH}$ of the medium. The chemical stability of chitosan is enhanced by several techniques such as cross linking (Du et al. 2009) carboxymethylation (Xu et al. 2009) grafting (Morimoto et al. 2002) blending (Wang and Kuo 2008; Ngah et al. 2004) coating (Popuri et al. 2009) and sulphonation (Holme and Perlin 1997). Among all the techniques cross linking is mainly focused because of its simple procedure and there are enormous opportunities to form macromolecular super structures for various specific applications (Crini 2005). Several studies have emphasized that chitosan and its modified form (cross linking coating and blending) is a very efficient adsorbent to remove various toxic and strategic metals (Gerente et al. 2007; Chang et al. 2007).

Vermiculite refers to a class of hydrated ferromagnesium-aluminum silicates that contains various mineral groups. It looks like mica and has a lattice layer of $\mathrm{Mg}^{2+}$ (or) $\mathrm{K}^{+}$with water molecules (McBride 1994). Vermiculite can adsorb metals via two mechanisms: (1) cation exchange at the planar sites, resulting from the interaction between metal ions and negative permanent charge (outer-sphere complexes) and (2) formation of inner-sphere complexes through $\mathrm{Si}-\mathrm{O}-$ and Al-O-groups at the clay particle edges. Removal of toxic metals such as $\mathrm{Cd}(\mathrm{II}), \mathrm{Pb}$ (II) and $\mathrm{Cu}(\mathrm{II})$ by vermiculite (Allan et al. 2007; Prakash et al. 2012) has also been reported.

Multiwall carbon nanotubes with the magnetic properties of iron oxide have been used as a composite adsorbent for the adsorption of $\mathrm{Cr}$ (III) and it has been shown (Gupta et al. 2011) that the adsorption of $\mathrm{Cr}$ (III) is strongly dependent on contact time, agitation speed and $\mathrm{pH}$ in the batch mode and on flow rate and the bed thickness in the fixed bed mode. Chemical treatment technologies for wastewater recycling has been reviewed in (Gupta et al. 2012) and a brief guideline for the selection of the appropriate technologies for specific applications has been neatly evaluated. The carbon occurs adsorbent prepared from carbon slurry is reported (Jain et al. 2003) to be efficient and can be used for the removal of dyes from solution.

Bottom ash and despoiled soya have been used as adsorbents for the removal of a hazardous azodye and reported in Mittal et al. (2008). A hazardous textile dye, safranin-T, has been successfully photo degraded using $\mathrm{Tio}_{2}$ as catalyst and reported in Gupta et al. (2007). The adsorption performance of the materials namely bottom ash, a power plant water and de-oiled soya waste has been appreciable while employing batch and column methods as reported (Mittal et al. 2010). The hexavalent chromium, $\mathrm{Cr}(\mathrm{VI})$ has been successfully bioadsorbed on raw and acid treated Oedogonium hatei from aqueous solutions (Gupta et al. 2010c).

From the available literature reports, it is observed that the investigations on ternary blends with the presence of cross linking agents likely to enhance the thermal and chemical stability for the removal of heavy metals are scanty and inadequate. Hence, in the present study an attempt has been made to investigate the possibility of the vermiculite blended chitosan in the presence of glutaraldehyde as the cross linking agent for the adsorption of $\mathrm{Cr}(\mathrm{VI})$ and $\mathrm{Cd}(\mathrm{II})$ ions from the aqueous solution. Vermiculite is mixed with chitosan was prepared in ratios of $(1: 1),(3: 1)$ in the presence and absence of cross linking agent glutaraldehyde. The blend was characterized by using FT-IR, XRD, TGA and DSC techniques. The kinetic adsorption studies of these blends with chromium and cadmium in aqueous solution were evaluated using different isotherms. 


\section{Materials and methods}

\section{Instrumentation}

\section{FT-IR studies}

Fourier Transform Infra Red spectra of all the adsorbents of various combinations were recorded in the frequency range of 400-4000 $\mathrm{cm}^{-1}$ using Thermo Nicolet AVATAR 330 spectrophotometer. The samples were pressed into pellets with $\mathrm{KBr}$.

\section{$X$-ray diffraction studies}

X-ray diffractograms of powdered samples were obtained using a X-ray powder diffractometer (XRD-Shimadzu XDD1) with Ni-filter, $\mathrm{Cu} \mathrm{K} \alpha$, radiation source. The relative intensity was recorded in the scattering range $2 \theta$ of $10^{\circ}$ $90^{\circ}$.

\section{Thermogravimetric analysis}

Thermo gravimetric analysis of all the adsorbents with various combinations was conducted by SOT Q600. V8. This analysis is to find out the thermal stability of the synthesized polymer and the heating range is $20-50{ }^{\circ} \mathrm{C}$ and the heating rate is $20^{\circ} \mathrm{C}$ per min.

\section{Differential scanning calorimetric analysis}

The thermal behaviour of the adsorbents was studied using NET $2 \mathrm{SCH}$ DSC thermal analyzer. The sample was inserted into the $\mathrm{Al}$ pan and DSC scan was made from 30 to $300{ }^{\circ} \mathrm{C}$ in a nitrogen atmosphere at a heating rate of $20{ }^{\circ} \mathrm{C} \min ^{-1}$. The results were recorded and analyzed.

\section{Stock solution}

Stock solutions of chromium(VI) ions and cadmium ions were prepared (Dean 1995). All other concentration values, varying between 40 and $670 \mathrm{mg} \mathrm{l}^{-1}$ of $\mathrm{Cd}(\mathrm{II})$ were prepared by dilution from the stock solution. The initial $\mathrm{pH}$ of the working solution was obtained by adding small volumes of $0.5 \mathrm{~N} \mathrm{HNO}_{3}$ (for $\mathrm{pH} 2.0$ and 3.0), or acetate buffer $\left(\mathrm{CH}_{3} \mathrm{COOH} / \mathrm{CH}_{3} \mathrm{COONa}\right)$, for $3.0<\mathrm{pH}<6.0$.

\section{Preparation of adsorbent: chitosan mixed vermiculite}

The chitosan polymer solution was prepared by dissolving $1 \mathrm{~g}$ of chitosan in $2 \%$ acetic acid and mixed with a known weight of the vermiculite. The mixture was then stirred thoroughly in the presence of glutaraldehyde $(10 \mathrm{ml})$ as a cross linking agent at room temperature for $1 \mathrm{~h}$. Then the above prepared mixture were poured into a petri dish and dried in vacuum for $10 \mathrm{~h}$ to remove the solvent completely.

\section{Methodology for batch process of adsorption studies}

For the study of equilibrium isotherms, the adsorption studies were done at varying concentrations of the metal, i.e., $30,60,90,120,150,180$, and $210 \mathrm{mg}^{-1}$ of chromium and cadmium and keeping the amount of chitosan (2.0 $\left.\mathrm{g} \mathrm{l}^{-1}\right)$ constant at $\mathrm{pH}$ 5.0. Polymer blended solutions $(30 \mathrm{ml})$ were added to the reactor vessel. Solutions were stirred magnetically throughout the experiments. Samples $(100 \mu \mathrm{l})$ were taken from the feed cell into which metal was adsorbed and the solution is estimated for chromium and cadmium using the usual EDTA method (Prakash et al. 2012). Chromium and cadmium $\left(30 \mathrm{mg} \mathrm{l}^{-1}\right)$ were added to the reactor vessel. The reactor vessel is stirred magnetically throughout the experiments. Following the chromium and cadmium concentrations were estimated, the equilibrium isotherm was prepared by plotting uptake in $\mathrm{mg} \mathrm{g}^{-1}$ versus the equilibrium concentration of chromium and cadmium in $\mathrm{mg}^{-1}$.

\section{Removal of chromium and cadmium}

Synthetic solutions of $\mathrm{Cr}(\mathrm{VI})$ ions and $\mathrm{Cd}(\mathrm{II})$ ions were taken in stopper bottles and agitated with the prepared adsorbents separately at $30^{\circ} \mathrm{C}$ in orbit shaker at fixed speed of $160 \mathrm{rpm}$. The extent of heavy metal removal was investigated separately by changing the amount of adsorbent, contact time and different $\mathrm{pH}$ of the solution. After attaining the equilibrium the adsorbent was separated by treating it with suitable reagents after leaching the metals from the adsorbents. Analysis of the concentration of the metals has been done using atomic adsorption spectrophotometer (Varian AAA 220 FS). Chromium has been determined from the analysis by fixing the wave length at $357.9 \mathrm{~nm}$ and cadmium has been obtained by fixing the wavelength at $228.8 \mathrm{~nm}$.

\section{Results and discussion}

\section{Characterization}

Vermiculite blended chitosan were characterized by IR spectroscopy, X-ray diffraction, thermal gravimetric analysis (TGA/DTA), Differential Scanning Calorimetry (DSC). Further, kinetic analysis have also been reported and discussed. 


\section{FT-IR spectra analysis}

The FT-IR spectrum of chitosan gave a characteristic band at $3450 \mathrm{~cm}^{-1}$ which is attributed to $-\mathrm{NH}_{2}$ and $-\mathrm{OH}$ stretching vibration and the band for amide I at $1652 \mathrm{~cm}^{-1}$ is observed in the infrared spectrum of chitosan. The characteristic carbonyl stretching of chitosan observed at $1733 \mathrm{~cm}^{-1}$ and the broader peak at $1635 \mathrm{~cm}^{-1}$ corresponding to the chitosan $\mathrm{NH}_{2}$ band. In 3:1 ratio the peaks observed at $3421 \mathrm{~cm}^{-1}$ are due to $\mathrm{OH}$ stretching, $-\mathrm{NH}$ stretching and intermolecular hydrogen bonding. The peaks at 2935,1640 and $1579 \mathrm{~cm}^{-1}$ indicate asymmetric C-H stretching, $\mathrm{C}=\mathrm{O}$ stretching and $\mathrm{N}-\mathrm{H}$ bending respectively. The peaks at 1386, 1254, 1029 and $452 \mathrm{~cm}^{-1}$ arises due to $\mathrm{C}-\mathrm{H}$ bending, $\mathrm{O}-\mathrm{H}$ bending, $\mathrm{Si}-\mathrm{O}$ stretching, $\mathrm{Al}-\mathrm{O}$ stretching vibrations respectively. The IR spectrum of chitosan:vermiculite $(1: 1)$ shows the peak at $3430 \mathrm{~cm}^{-1}$ corresponding to the $-\mathrm{OH}$ stretching, $-\mathrm{NH}$ stretching, which may be due to intermolecular hydrogen bonding and polymeric association. The peaks at $2927,1605 \mathrm{~cm}^{-1}$ correspond to the asymmetric $\mathrm{C}-\mathrm{H}$ stretching and $\mathrm{N}-\mathrm{H}$ bending. The peaks at 1383,1021 and $460 \mathrm{~cm}^{-1}$ are due to the $\mathrm{C}-\mathrm{H}$ bending, $\mathrm{C}-\mathrm{OH}$ was stretching, $\mathrm{Si}-\mathrm{O}$ and $\mathrm{Al}-\mathrm{O}$ stretching vibrations.

The spectrum of chitosan:vermiculite+Glu (1:1), blend has a peak at $3000-3600 \mathrm{~cm}^{-1}$, which is due to $\mathrm{OH}$ stretching, $\mathrm{NH}$ stretching and intermolecular hydrogen bonding. The peak positions are slightly modified in the presence of cross linker. The peaks at 2938, 1713, 1583 and $1381 \mathrm{~cm}^{-1}$ correspond to the asymmetric $\mathrm{C}-\mathrm{H}$ stretching, $\mathrm{C}=\mathrm{O}$ stretching, $\mathrm{N}-\mathrm{H}$ bending and $\mathrm{C}-\mathrm{H}$ bending vibrations. The peak at 1020, 681, 499 and $450 \mathrm{~cm}^{-1}$ indicate the $\mathrm{C}-\mathrm{O}$ stretching, $\mathrm{N}-\mathrm{H}$ deformation and $\mathrm{Al}-\mathrm{O} \& \mathrm{Si}-\mathrm{O}$ stretching vibration respectively. The IR spectrum for the ratio of chitosan:vermiculite+Glu (3:1) has stretching and due to intermolecular hydrogen bonding. The peaks at $2927 \mathrm{~cm}^{-1}$ to aldehydic asymmetric and symmetric $\mathrm{CH}$ stretching, the peaks at $1716,1383 \mathrm{~cm}^{-1}$ the corresponds to $\mathrm{C}=\mathrm{O}$ stretching, $\mathrm{N}-\mathrm{H}$ bending and $\mathrm{C}-\mathrm{H}$ bending vibrations respectively. The peaks at 1022 and $449 \mathrm{~cm}^{-1}$ correspond to $\mathrm{C}-\mathrm{OH}$ stretching and $\mathrm{Al}-\mathrm{O}, \mathrm{Si}-\mathrm{O}$ stretching vibrations respectively.

The sharp peak observed at $1610 \mathrm{~cm}^{-1}$ may be due to $\mathrm{C}=\mathrm{N}$ (amide I band) of the Schiff's base formed between the free amino groups from the chitosan and aldehyde groups from glutaraldehyde which acts as a cross linking agent. In addition, the observed decrease in the intensity of the broad peak around may be attributed to the cross linking via acetalization reaction the glucosamine units of chitosan and aldehyde groups of glutaraldehyde. Similar observations were reported by Ruiz et al. (2000). An intensity of the sharp peak was observed at $1624 \mathrm{~cm}^{-1}$ which may be due to the $\mathrm{N}-\mathrm{H}$ bending (amide II band).
The increase is the chitosan composition in blend leads to more number of $-\mathrm{NH}$ functional groups. When chitosan was mixed with vermiculite the absorption peaks were observed at lower frequencies, due to the intermolecular hydrogen bonding of chitosan with vermiculite (Xie and Wang 2009).

When chitosan was blended with vermiculite in the presence of glutaraldehyde as cross linking agent an intensity of the sharp peak was observed at $1610 \mathrm{~cm}^{-1}$ which may be due to the $\mathrm{C}=\mathrm{N}$ (amide I band) of the formed Schiff's base between the free amino groups that are present in the chitosan and aldehyde groups of the cross-linker glutaraldehyde (Ruiz et al. 2000).

\section{$X$-ray diffraction studies}

Figure $1 \mathrm{a}, \mathrm{b}$ show the XRD spectrum of chitosan:vermiculite (1:1) and (3:1). From the XRD spectrum, the appearance of short sharp peaks at $2 \theta=19^{\circ}, 33^{\circ}$ and $36^{\circ}$ for $1: 1$ and three sharp peaks at $2 \theta=11^{\circ}, 15^{\circ}$ and $25^{\circ}$ for 3:1 indicates high crystalline nature of blends.

In the presence of glutaraldehyde, the XRD spectrum of chitosan:vermiculite for ratio (1:1) and (3:1) are shown in Fig. 1c, d. The XRD peaks are observed at $2 \theta=19^{\circ}, 26^{\circ}$, $34^{\circ}$ for $1: 1$ and at $2 \theta=25^{\circ}, 39^{\circ}$ for $3: 1$. From the XRD data it is clear that the nature of the sample is semi crystalline in nature for 1:1 ratio, where as in the case of 3:1, the observation of two long sharp peaks at $2 \theta=25^{\circ}$ indicate crystalline nature of the blend.

\section{Thermo gravimetric analysis (TGA)}

Figure 2a, b represents the thermogram of chitosan:vermiculite mixture for (1:1) and (3:1) ratios. The maximum weight loss takes place at the temperature range from 250 to $500{ }^{\circ} \mathrm{C}$. Around $54.57 \%$ of the sample had disintegrated at the temperature of approximately $731.25{ }^{\circ} \mathrm{C}$. At the end of the experiment, $45.43 \%$ of the sample was obtained as a residue. $12 \%$ of the sample had disintegrated at the temperature range of $510-860{ }^{\circ} \mathrm{C}$. It may be due to loss of water. In the case of 3:1 ratio, the maximum weight loss takes place at the temperature range from 200 to $663{ }^{\circ} \mathrm{C}$. Around $63.10 \%$ of the sample had disintegrated at the temperature of about $657.12{ }^{\circ} \mathrm{C}$. At the end of the experiment $36.90 \%$ of the sample remained as a residue. $15 \%$ of the sample had disintegrated at a temperature range of $450-200{ }^{\circ} \mathrm{C}$.

Figure $2 \mathrm{c}, \mathrm{d}$ represents the thermogram chitosan:vermiculite $(1: 1)+$ Glu $(10 \mathrm{ml})$ ratio. The maximum weight loss takes place at the temperature range from 150 to $375{ }^{\circ} \mathrm{C}$. Around $75.311 \%$ of the sample had disintegrated at the end of the experiment. $24.68 \%$ of the sample remained as a residue. $5 \%$ of the sample had disintegrated at the temperature range of $500-150{ }^{\circ} \mathrm{C}$. The weight loss 


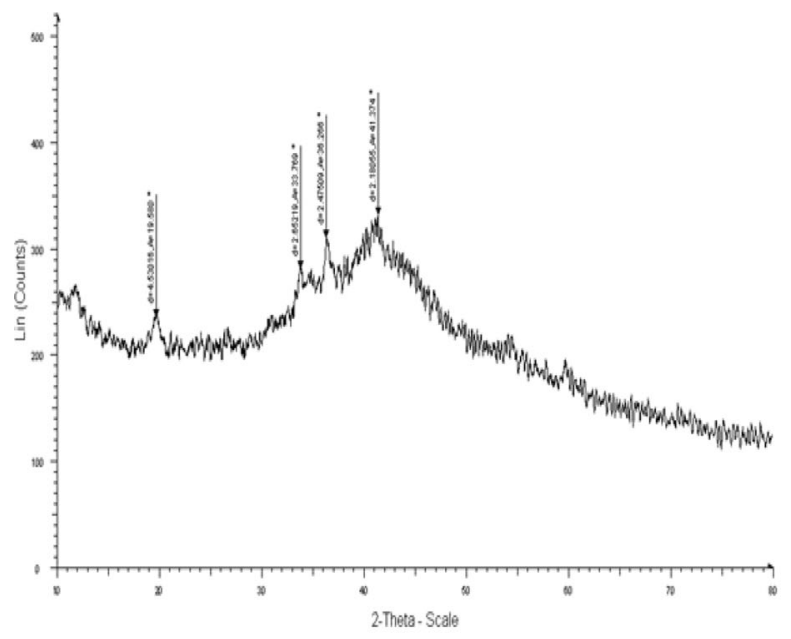

(a)

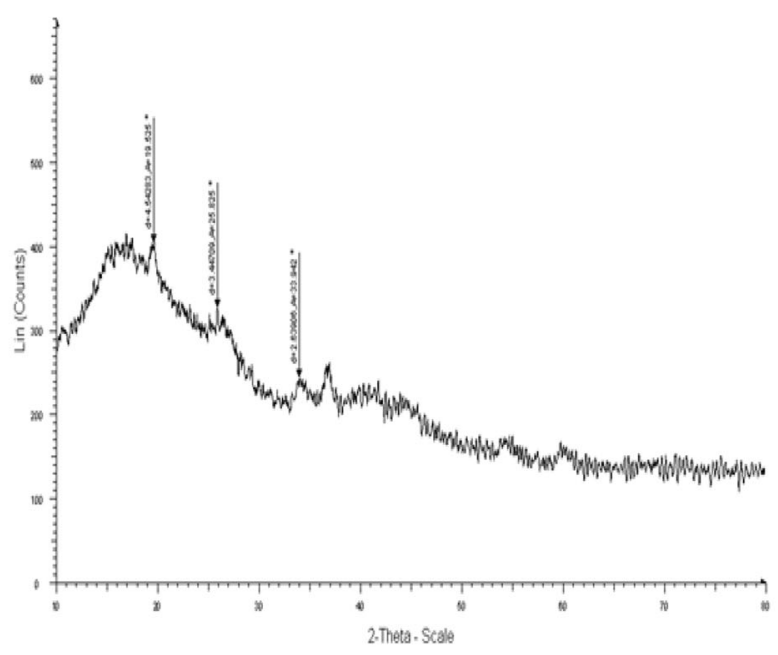

(c)

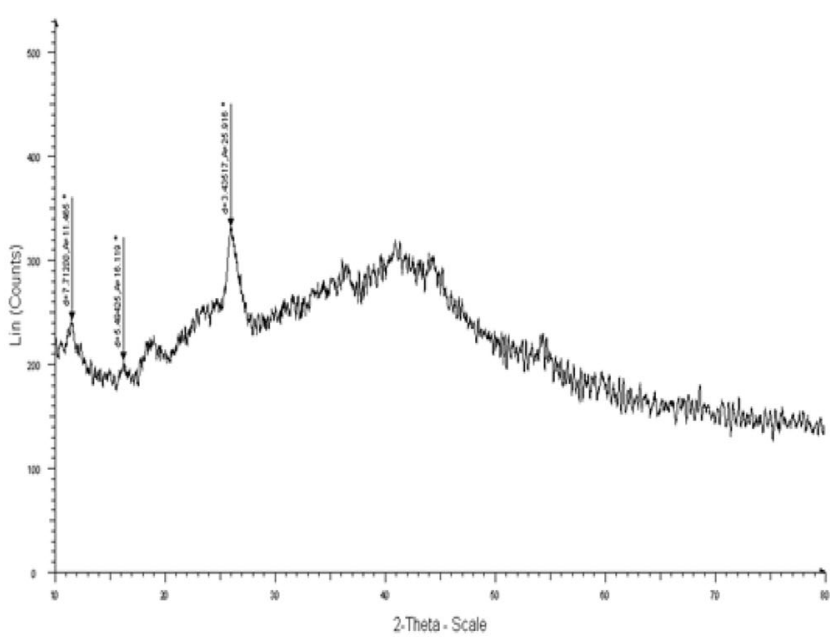

(b)

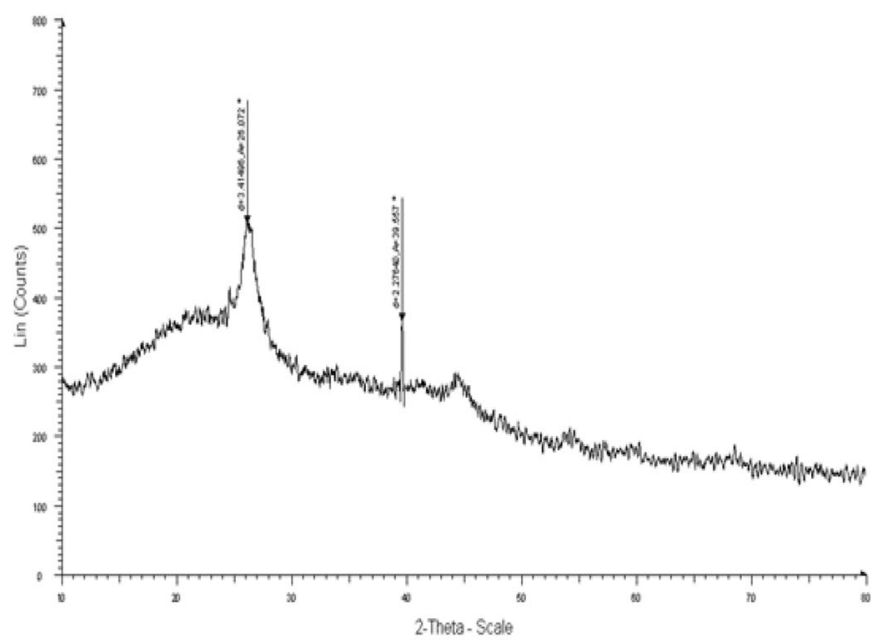

(d)

Fig. 1 a XRD diffractogram of chitosan mixed vermiculite (1:1), b XRD diffractogram of chitosan mixed vermiculite (3:1), c XRD diffractogram of chitosan mixed with vermiculite (1:1)+Glu, d XRD diffractogram of chitosan mixed with vermiculite (3:1)+Glu

between 50 and $150{ }^{\circ} \mathrm{C}$ may be due to water loss. The maximum weight loss occurs at 150 and $375{ }^{\circ} \mathrm{C}$. The weight loss may be due to the decomposition of the $-\mathrm{CH}_{2}$ linkages, H-bonding and other interaction between the two polymers. After $400{ }^{\circ} \mathrm{C}$ there was a sudden rise in the decomposition of the pyranose ring of the polysaccharides. When we compare the thermal stability with or without cross linking agent, the cross linked chitosan was thermally more stable.

Based on Fig. 2d, the thermogram of chitosan:vermiculite+Glu (3:1), the maximum weight loss takes place at the temperature range from 200 to $400{ }^{\circ} \mathrm{C}$. Around $63.552 \%$ of the sample had disintegrated at the temperature range of $700{ }^{\circ} \mathrm{C}$. At the end of the experiment, $36.448 \%$ of the sample remained as a residue. The maximum weight loss that occurred at $200-400{ }^{\circ} \mathrm{C}$ may be due to the decomposition of the $-\mathrm{CH}_{2}$-linkage, $\mathrm{H}$-bonding and other interaction between the polymers.

\section{Adsorption experiments}

\section{Experimental procedure}

Series of experiments were performed to evaluate the influence of the following variables: initial $\mathrm{pH}$ value of the solution, contact time, and adsorbent dosage. The batch experiments were performed by adding chitosan mixed vermiculite to a $25 \mathrm{ml}$ solution containing $\mathrm{Cr}(\mathrm{VI})$ ions and $\mathrm{Cd}(\mathrm{II})$ ions under intermittent stirring, at room temperature $\left(25 \pm 0.5{ }^{\circ} \mathrm{C}\right)$ and, with the exception of only 


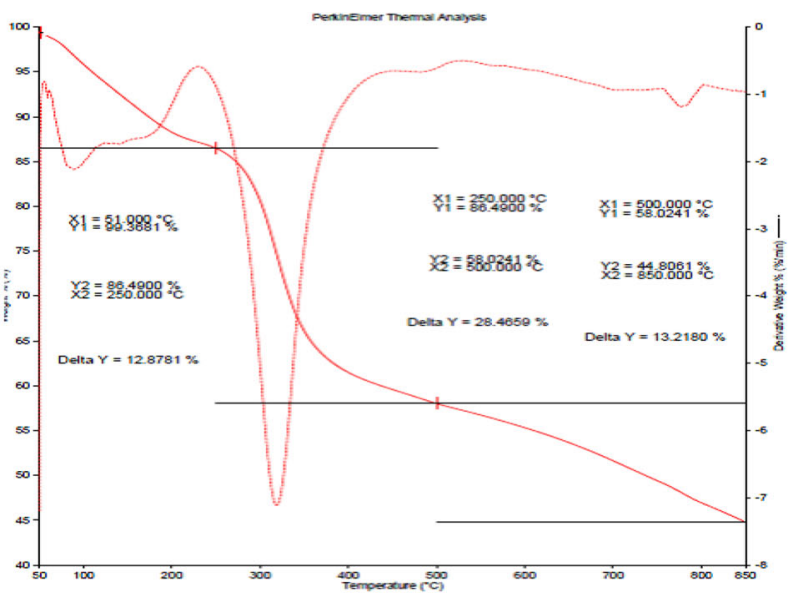

(a)

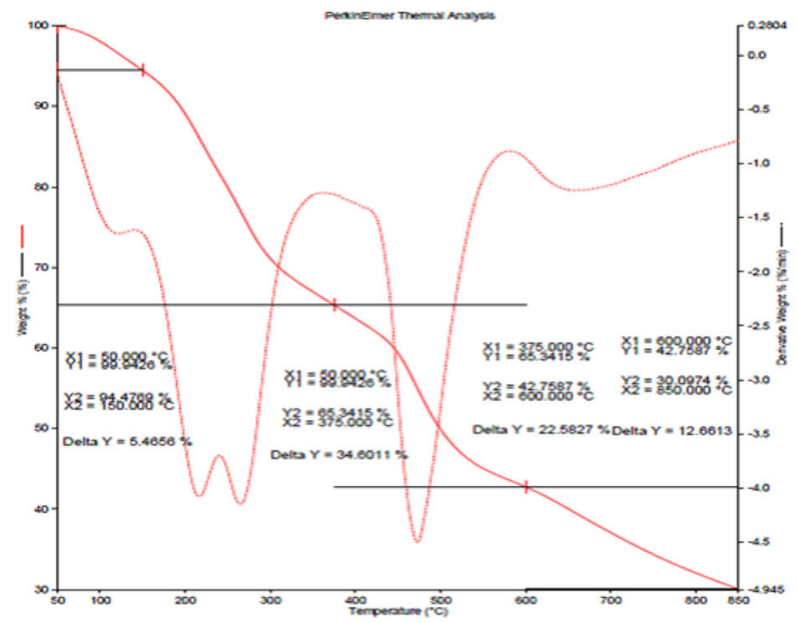

(c)

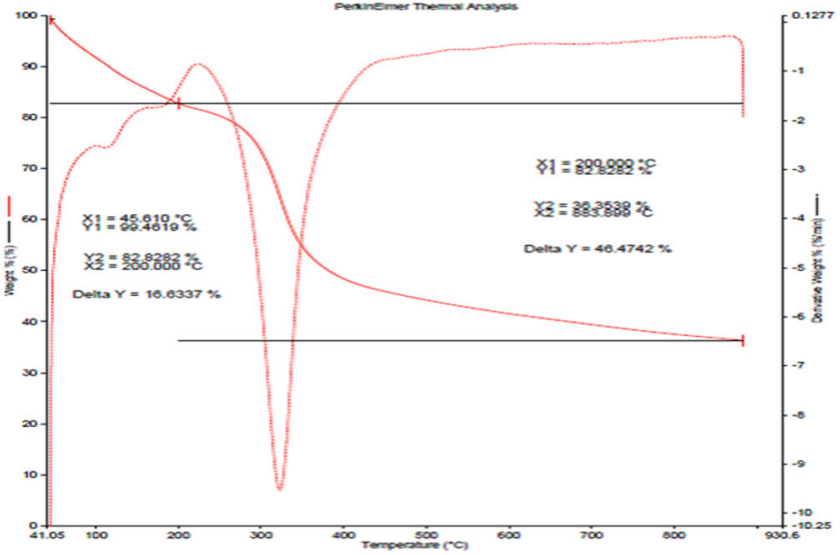

(b)

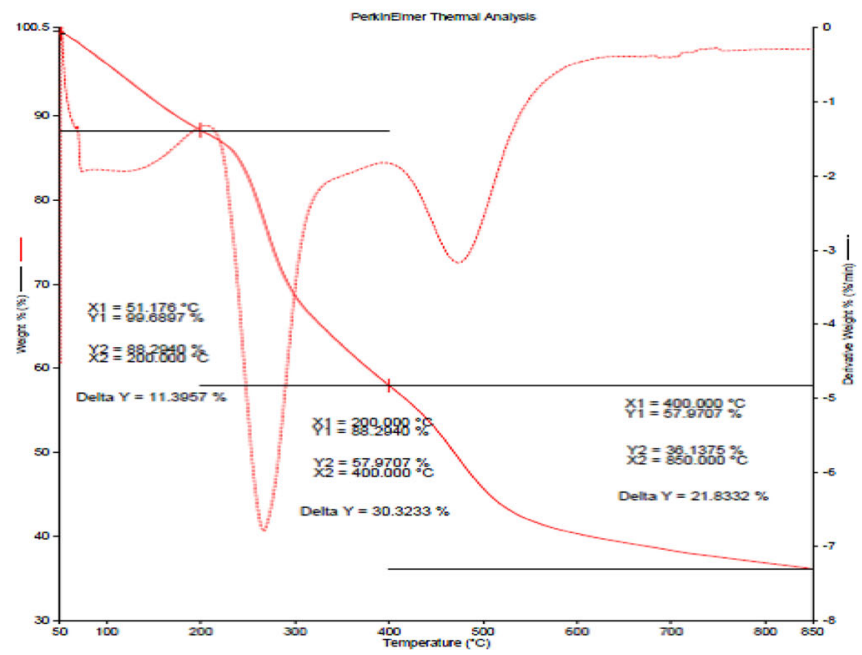

(d)

Fig. 2 a TGA of chitosan mixed with vermiculite (1:1), b TGA of chitosan mixed with vermiculite (3:1), $\mathbf{c}$ TGA of chitosan mixed with vermiculite (1:1)+Glu, d TGA of chitosan mixed with vermiculite (3:1)+Glu

one series, at a constant contact time of $24 \mathrm{~h}$. The influence of the initial solution $\mathrm{pH}$ on $\mathrm{Cr}(\mathrm{VI})$ and $\mathrm{Cd}(\mathrm{II})$ ions capacity of adsorption onto chitosan mixed vermiculite was investigated over the $4.0-8.0 \mathrm{pH}$ range, at a constant dosage of chitosan mixed vermiculite. To evaluate the effect of adsorbent dosage on $\mathrm{Cr}(\mathrm{VI})$ and $\mathrm{Cd}(\mathrm{II})$ adsorption, the metal ion solutions of a constant concentration (71.3 and $74.3 \mathrm{mg} \mathrm{l}^{-1}$ ) was treated with variable dosages of chitosan mixed vermiculite. (Resulting in adsorbent concentrations in the mixture from 5 to $40 \mathrm{~g} \mathrm{l}^{-1}$, at $\mathrm{pH}$ 5.0 of the initial solution). The influence of contact time of both the metal ions concentration on chitosan mixed vermiculite adsorption capacity was studied over the 30-360 min range, at $\mathrm{pH} 5.0$ of the initial solution and constant dosage of chitosan mixed vermiculite $\left(5 \mathrm{~g} \mathrm{l}^{-1}\right.$ concentration in the reaction volume). It is seen from
Fig. 3, that cadmium recovery is higher when compared to chromium recovery at all times. It is seen from the graph that the complexes of $\mathrm{Cr}^{6+}$ and $\mathrm{Cd}^{2+}$ behave in the same manner and cadmium and chromium complexes are stable during the studies. This may also be due to the stability of the complexes, cadmium complex is more stable compared to chromium complex (Prakash et al. 2012). The percentage of removal of cadmium is always higher compared to chromium at all contact time Fig. 3. Since cadmium is easily polarizable and charge to size ratio is less for cadmium compared to chromium the recovery of cadmium is more at all time compared to chromium. $\left(\mathrm{Cr}^{6+}=11.6 \times 10^{-24}\right.$ and $\mathrm{Cd}^{2+}=7.2 \times$ $10^{-24}$ ) Fig. 3 also shows the effect of contact time on the removal of chromium and cadmium metals in the artificial wastewater. 


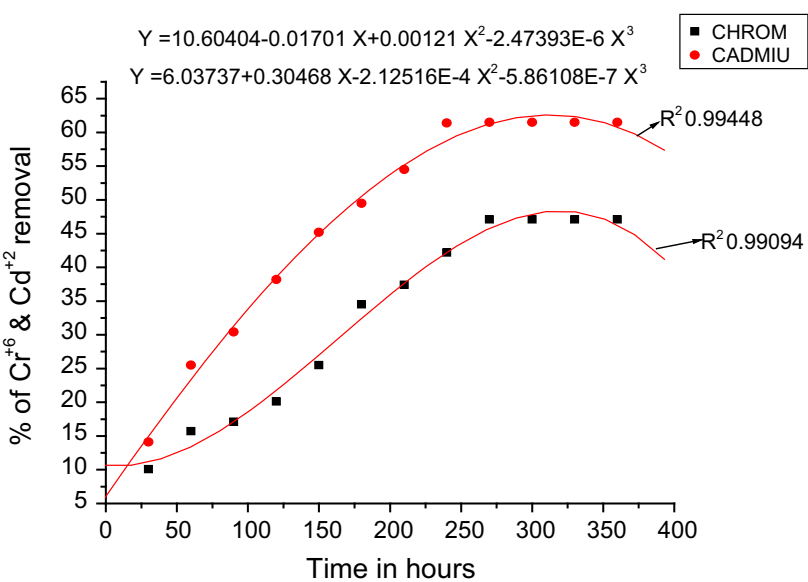

Fig. 3 Percentage of metal removal as a function of time

\section{Percentage of metal removal as a function of $\mathrm{pH}$}

The adsorption process is strongly affected by the $\mathrm{pH}$ of the solution. The effect of $\mathrm{pH}$ change on adsorption was studied for both the metals by changing the $\mathrm{pH}$ of the contents from 4 to 8 , using dilute solutions of $\mathrm{HCl}$ and $\mathrm{NaOH}$. The observation shows that the maximum adsorption of both the metals took place in acidic media and this is evident from Fig. 4. The maximum adsorption for $\mathrm{Cr}(\mathrm{VI})$ was observed at $\mathrm{pH} 5$ (72\% removal) and for cadmium at pH 5.5 (71 \% removal) (Prakash et al. 2012). In general, at very high and very low $\mathrm{pH}$ values, the surface of the adsorption is surrounded mainly by $\mathrm{H}^{+}$and $\mathrm{OH}^{-}$ions respectively. These positively and negatively charged ions may compete with the metal ions and as a result, adsorption decreases. That's why metal ions show low adsorption at very high and low pH values (Saeed and Iqbal 2003). Influence of $\mathrm{pH}$ on adsorption phenomenon is also related with the functional groups present on the bio-adsorbent.

\section{The percentage removal of chromium and cadmium using chitosan mixed with vermiculite at different adsorbent dosage}

Various operational parameters like solid/liquid ratio, $\mathrm{pH}$, contact time, metal ion concentration and temperature were employed to determine the adsorption characteristics of chitosan biopolymers for heavy metal ion adsorption from aqueous solutions. The effect of the solid/liquid ratio for chromium adsorption on chitosan biopolymer was examined. In these experiments, operational parameters were kept constant $T=298 \mathrm{~K}, C_{0}=200 \mathrm{mg}^{-1}$ and the $\mathrm{pH}$ was varied initially for various time intervals. Figure 5 indicates that the percentage of adsorption of chromium and cadmium increases steadily with, solid to liquid ratio of $1-3 \%$. Whereas, at $4-6$ there is saturation, increasing

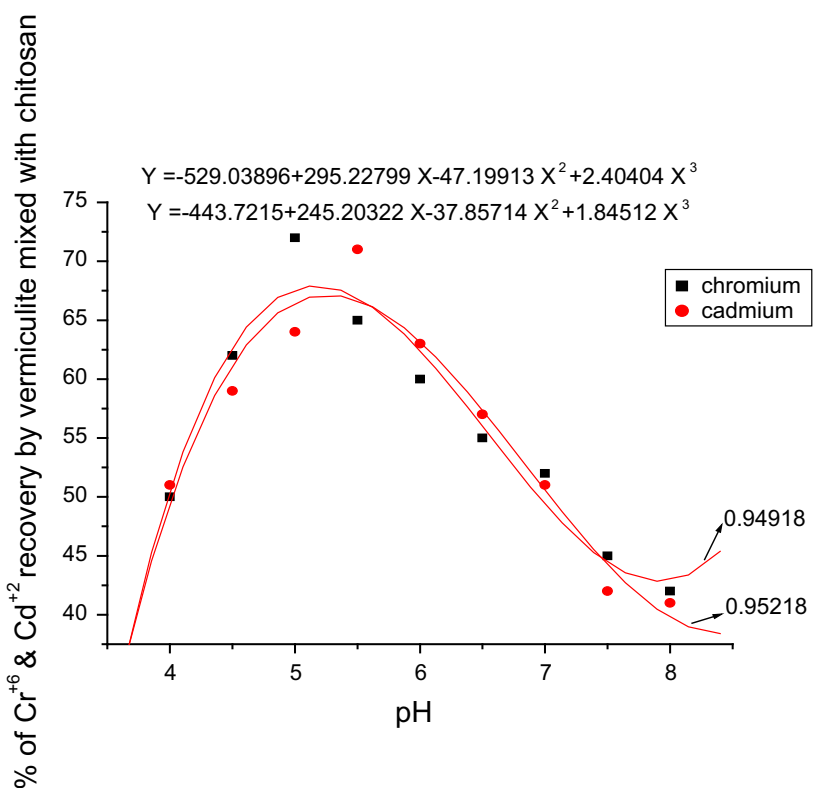

Fig. 4 Percentage of $\mathrm{Cr}(\mathrm{VI})$ and $\mathrm{Cd}(\mathrm{II})$ recovery by chitosan mixed with vermiculite at different $\mathrm{pH}$

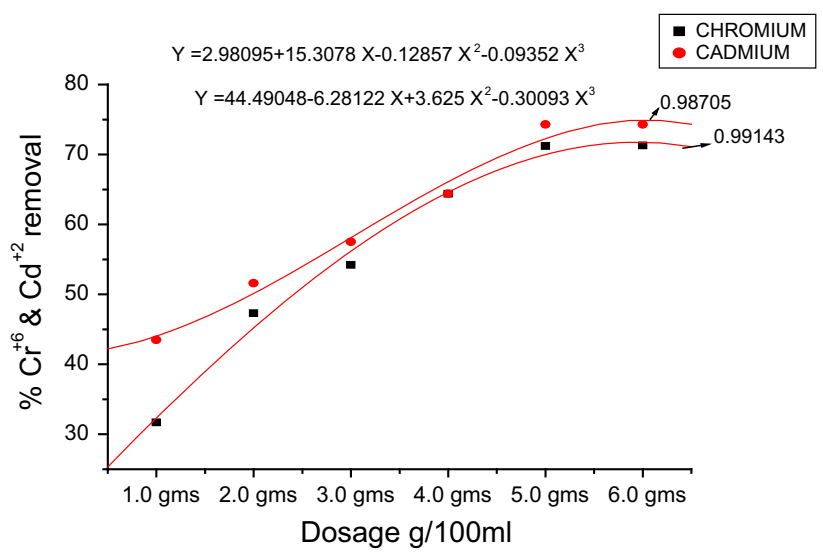

Fig. 5 Percentage removal of chromium and cadmium using chitosan mixed with vermiculite at different adsorbent dosage

the solid to liquid ratio for chitosan biopolymers increases the number of active sites available for adsorption.

\section{Effect of contact time}

It has been observed that at a constant concentration of metal ions and fixed amount of adsorbent, the adsorption efficiency increases with increase in the contact time up to a certain level. Figure 5 shows that the adsorption rate first increased rapidly, but after reaching the optimum time value, the removal efficiency slightly decreased with an increase in the contact time. The effect may be due to the saturation of adsorption sites with metal ions on the solid particle. The initial optimum contact time for $\mathrm{Cr}(\mathrm{VI})$ was 


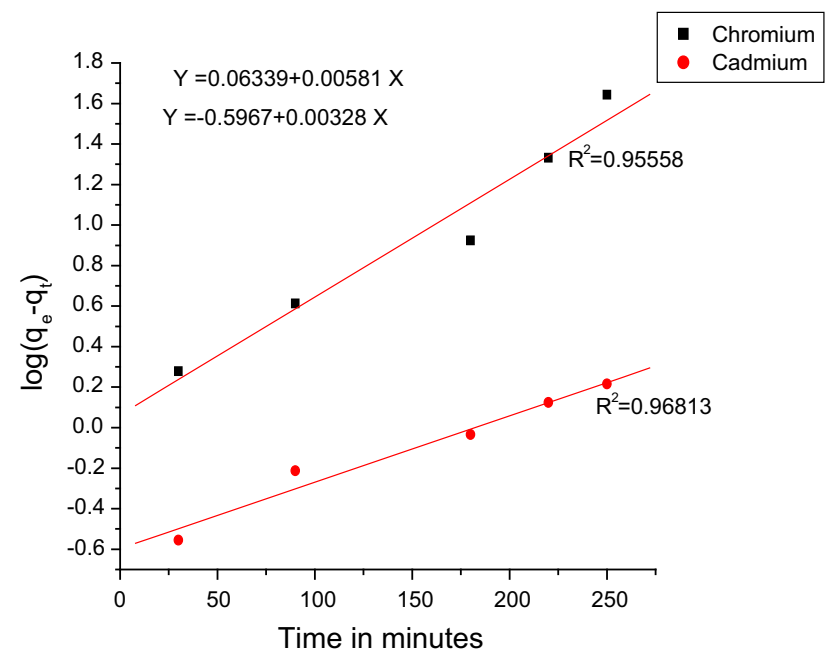

Fig. 6 Plot of $\ln \left(q_{\mathrm{e}} / q_{\mathrm{e}}-q\right)$ versus time in chromium and cadmium

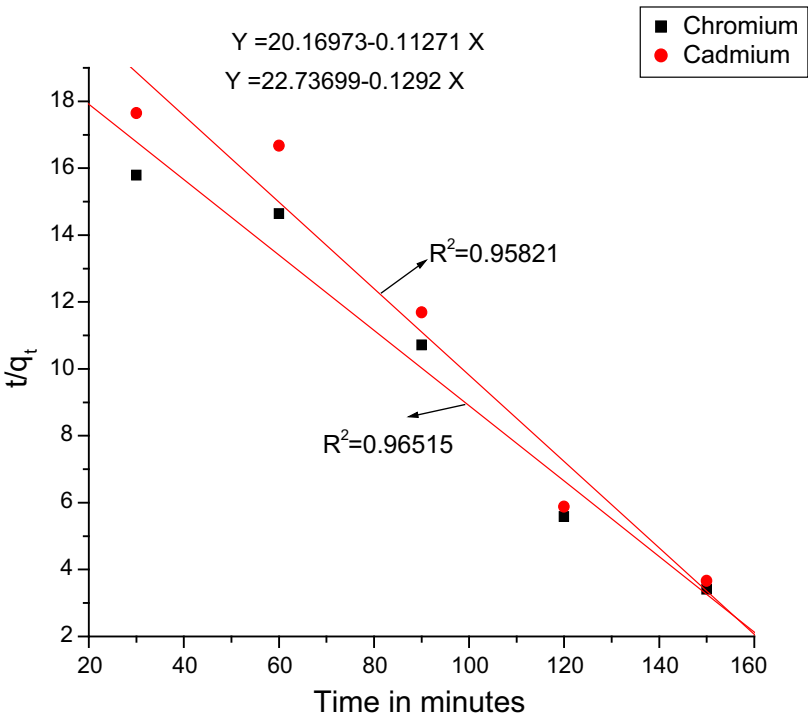

Fig. 7 Plot of $t / q$ versus time in chromium and cadmium

300 min with $59.2 \%$ adsorption and $300 \mathrm{~min}$ for $\mathrm{Cd}(\mathrm{II})$ with $71.5 \%$ adsorption. The slight decrease in adsorption after the optimum contact time may be due to the breakage of newly formed weak adsorption bonds due to the constant shaking.

\section{Kinetics of adsorption}

\section{Pseudo first and second order kinetics of adsorption}

The sorption data of $\mathrm{Cr}(\mathrm{VI})$ and $\mathrm{Cd}(\mathrm{II})$ uptake by chitosan:vermiculite adsorbent was fitted using Lagergren pseudo first and second order model and these are given in
Figs. 6 and 7. The linearized form of the first order Lagergren equation is given as Eq. 1.

$\log \left(q_{\mathrm{e}}-q_{\mathrm{t}}\right)=\log q_{\mathrm{e}}-\frac{K_{1, \mathrm{ads}}}{2.303} t$

The pseudo-second-order Eq. 2

$\frac{t}{q}=\frac{1}{k_{2, \mathrm{ads}} q_{\mathrm{e}}^{2}}+\frac{t}{q_{\mathrm{t}}}$

where $q_{\mathrm{e}}$ is the mass of metal adsorbed at equilibrium $\left(\mathrm{mg} \mathrm{g}^{-1}\right), q_{\mathrm{t}}$ the mass of metal at time (min), $k_{1}$, ads the pseudo first order reaction rate of adsorption (per min), $k_{2}$, ads the pseudo second order rate constant of adsorption $\mathrm{mg} \mathrm{g}^{-1} \min ^{-1}$. A comparison between the two kinetic models suggested is presented in Table 1. These facts suggest that the obtained $\mathrm{Cr}(\mathrm{VI})$ and $\mathrm{Cd}(\mathrm{II})$ adsorption onto chitosan mixed vermiculite kinetic data followed the pseudo second order kinetic model which describes the biosorption as the rate limiting step (Hanif et al. 2007).

\section{Adsorption isotherm models}

\section{Effect of adsorbent mass}

Adsorption to a maximum of $5 \mathrm{~g} / 100 \mathrm{ml}$ (using $50 \mathrm{ppm}$ metal solution) for $\mathrm{Cr}(\mathrm{VI})$ and $5 \mathrm{~g} / 100 \mathrm{ml}(10 \mathrm{ppm}$ metal solution) for $\mathrm{Cd}(\mathrm{II})$. By increasing the quality of adsorption beyond the optimal mass, there is no significant change in the removal efficiency. These results indicate that the removal efficiency is directly related to the number of available adsorption sites. Once equilibrium is attained there is no effect on adsorption efficiency. The optimum adsorbent mass is $5 \mathrm{~g} / 100 \mathrm{ml}$ for both metals with $71.3 \%$ removal of $\mathrm{Cr}(\mathrm{VI})$ and $74.3 \%$ removal of $\mathrm{Cd}(\mathrm{II})$.

\section{Adsorption isotherms}

Langmuir adsorption isotherms The Langmuir is used to describe the experimental adsorption isotherm. The Langmuir isotherm equation may be formulated as

$\frac{C_{\mathrm{eq}}}{C_{\mathrm{ads}}}=\left(\frac{1}{Q b}\right)+\left(\frac{C_{\mathrm{eq}}}{Q}\right)$

where non linearity is indicated in Figs. 8 and 9. From this it is not possible to correlate to the isotherm with the experimental data and it is clear that the experimental data is not following Langmuir isotherm. Another essential dimensionless equilibrium constant of Langmuir isotherm is $R_{\mathrm{L}}$ which is applied in many operations and is expressed as:

$R_{\mathrm{L}}=\frac{1}{1+b C_{\mathrm{i}}}$ 
Table 1 Comparison between Lagergren pseudo first and second order kinetic of adsorption

\begin{tabular}{|c|c|c|c|c|c|c|c|}
\hline \multirow[t]{2}{*}{ Metal ion } & \multicolumn{3}{|c|}{ Pseudo first order kinetic model } & \multirow{2}{*}{$\begin{array}{l}\text { Experimental value } \\
q_{\mathrm{e}}\left(\mathrm{mg} \mathrm{g}^{-1}\right)\end{array}$} & \multicolumn{3}{|c|}{ Pseudo second order kinetic model } \\
\hline & $q_{\mathrm{e}}\left(\mathrm{mg} \mathrm{g}^{-1}\right)$ & $k_{1}\left(\min ^{-1}\right)$ & $R^{2}$ & & $q_{\mathrm{e}}\left(\mathrm{mg} \mathrm{g}^{-1}\right)$ & $k_{2}\left(\mathrm{~g} \mathrm{mg}^{-1} \min ^{-1}\right)$ & $R^{2}$ \\
\hline $\mathrm{Cr}(\mathrm{VI})$ & 1071.86 & 0.001962 & 0.9555 & 124 & 360.73 & 0.005037 & 0.9582 \\
\hline $\mathrm{Cd}(\mathrm{II})$ & 563.09 & 0.003804 & 0.96813 & 132 & 169.72 & 0.005231 & 0.9651 \\
\hline
\end{tabular}

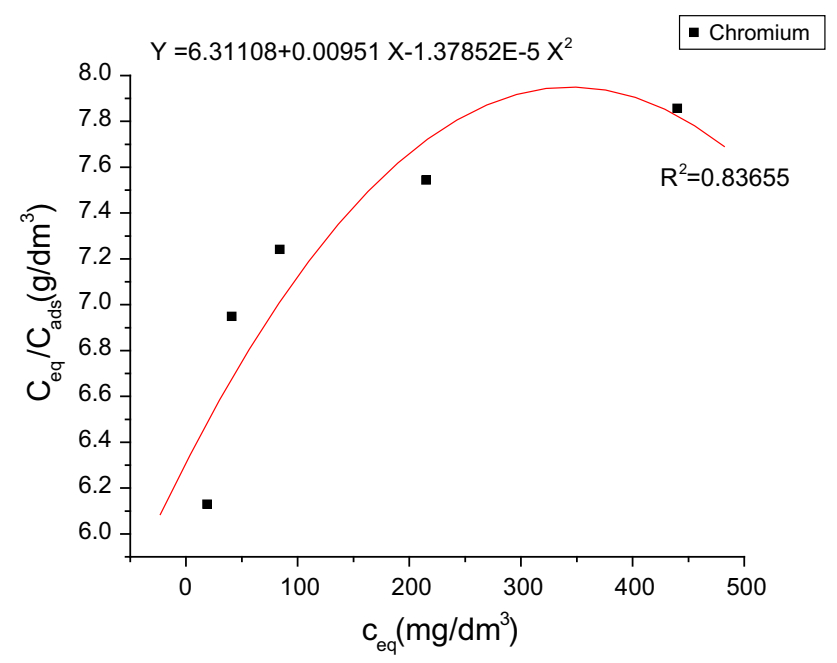

Fig. 8 Langmuir isotherm plot for chromium

where, $C_{\mathrm{i}}$ the initial concentration is the analyst in the solution. If $R_{\mathrm{L}}>1$, then it is considered unfavourable. $R=1$ corresponds to linear and $0<R<1$ is favourable (Table 2).

Freundlich adsorption isotherms The Freundlich model is used in essential of adsorption concentration of the adsorbate on the adsorbent surface (Freundlich 1926) and expressed as:

$C_{\mathrm{ads}}=K C_{\mathrm{eq}}^{\frac{1}{n}}$

The linearized (Figs. 10, 11) form of this equation is expressed as

$\log C_{\text {ads }}=\frac{1}{n} \log C_{\text {eq }}+\log K$

whereas, $1 / n$ is Freundlich characteristic constant related to energy, and $K$ is the maximum adsorption capacity. Both $n$ and $K$ are temperature dependant. By plotting $\log C_{\text {ads }}$ against $\log C_{\text {eq }}$, if a straight line is obtained, then the value of $1 / n$ and $K$ can be calculated from the slope and intercept. At the regions of moderate coverage Freundlich isotherm is similar to the Langmuir isotherm. Values of $1 / n$ indicate the steepness or flatness of the slopes. $1 / n$ close to 1

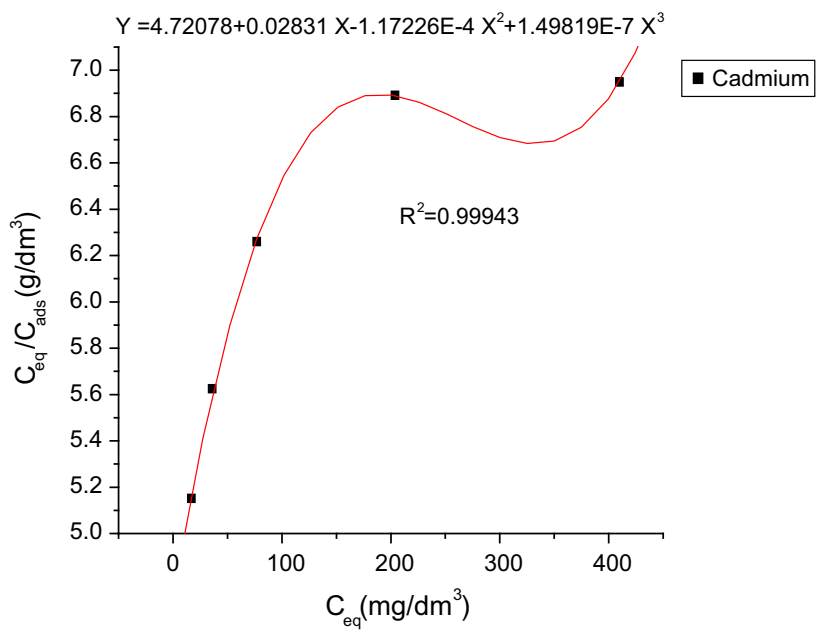

Fig. 9 Langmuir isotherm plot for cadmium

Table 2 Adsorption isotherm constant, $C_{\max }$ and correlation coefficients

\begin{tabular}{lllll}
\hline Metal ions & \multicolumn{4}{l}{ Langmuir constants } \\
\cline { 2 - 5 } & $K L\left(\mathrm{dm}^{3} \mathrm{~g}^{-1}\right)$ & $b\left(\mathrm{dm}^{3} \mathrm{mg}\right)^{-1}$ & $C_{\max }\left(\mathrm{mg} \mathrm{g}^{-1}\right)$ & $R^{2}$ \\
\hline $\mathrm{Cr}(\mathrm{VI})$ & 6.642 & 0.003139 & 2115.96 & 0.8365 \\
$\mathrm{Cd}(\mathrm{II})$ & 5.571 & 0.004061 & 1371.83 & 0.9994
\end{tabular}

indicates the steep slope and high adsorption capacity and equilibrium concentrations which diminishes at low equilibrium concentrations. On the other hand $1 / n \ll 1$ indicates a flat slope and adsorption capacity is slightly reduced at low equilibrium concentration (Faust and Aly 1987).

Adsorption isotherms results Langmuir and Freundlich The adsorption isotherm is fundamental in describing the interactive behaviour between solutes and adsorbent (Chiou and Li 2003; Ofomoja and Ho 2006). According to Ofomaja and Ho (2006), the isotherm yields certain constant values, which expresses the surface properties and affinity of the adsorbent. It also plays an important role in the design of an adsorption system.

The parameter indicates the effect of separation factor on isotherm shape according to Table 3 . The values of $R_{\mathrm{L}}$ 
Chromium

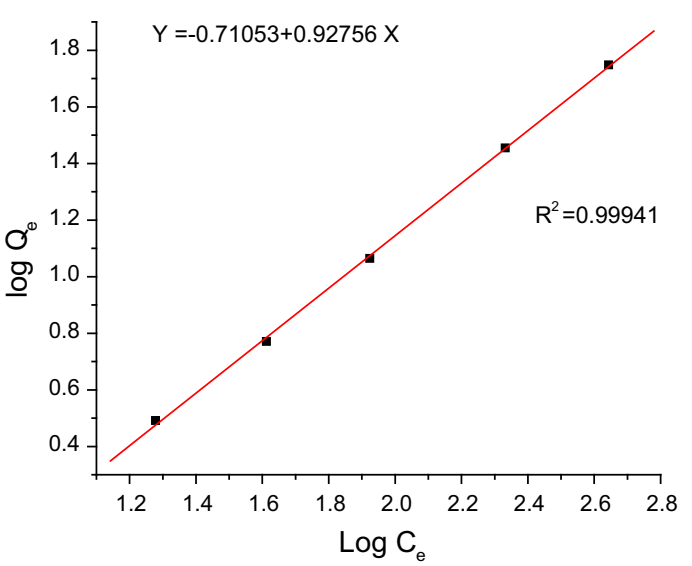

Fig. 10 Freundlich isotherm plot for chromium

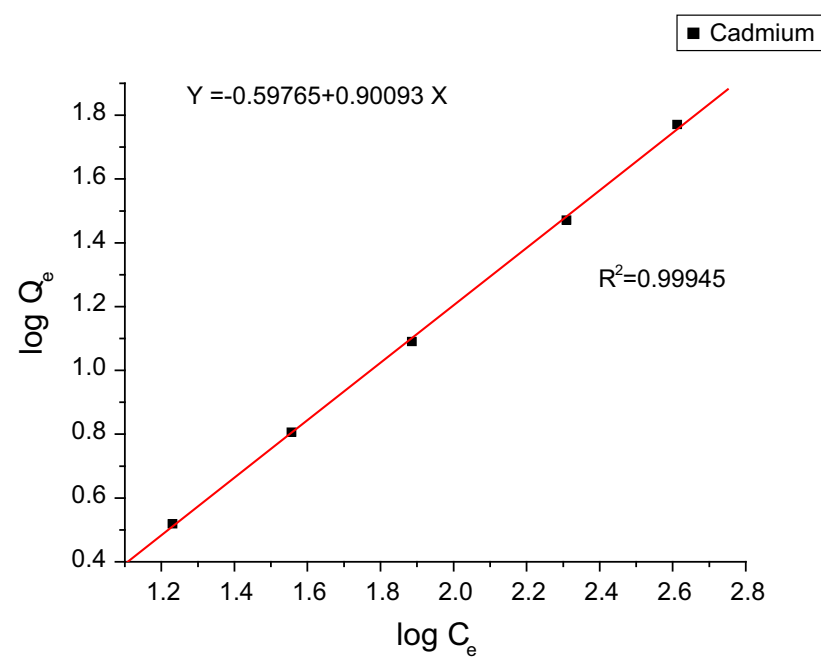

Fig. 11 Freundlich isotherm plot for cadmium

Table 3 Adsorption isotherm constant Freundlich

\begin{tabular}{llll}
\hline Metal ions & \multicolumn{3}{l}{ Freundlich constants } \\
\cline { 2 - 4 } & $K$ & $n$ & $R^{2}$ \\
\hline $\mathrm{Cr}(\mathrm{VI})$ & 0.1948 & 1.0780 & 0.9994 \\
$\mathrm{Cd}(\mathrm{II})$ & 0.2526 & 1.1100 & 0.9994 \\
\hline
\end{tabular}

calculated for different initial metal ion concentration are given in Table 4. If the $R_{\mathrm{L}}$ values are in the range of $0<R_{\mathrm{L}}<1$, it indicates that the adsorption of $\mathrm{Cr}(\mathrm{IV})$ and $\mathrm{Cd}(\mathrm{II})$ onto chitosan beads are favourable. Thus, chitosan beads are favourable adsorbents. The mechanism of ion
Table $4 \quad R_{\mathrm{L}}$ values based on Langmuir adsorption

\begin{tabular}{cccc}
\hline $\begin{array}{l}\text { Metal } \\
\text { ions }\end{array}$ & $\begin{array}{l}\text { Initial concentration } C_{0} \\
\left(\mathrm{mg} \mathrm{dm}^{-3}\right)\end{array}$ & $\begin{array}{l}\text { Final concentration } C_{\mathrm{f}} \\
\left(\mathrm{mg} \mathrm{dm}^{-3}\right)\end{array}$ & $\begin{array}{l}R_{\mathrm{L}} \\
\text { values }\end{array}$ \\
\hline Cr(VI) & 1000 & 440 & 0.4200 \\
ion & 500 & 215 & 0.5970 \\
& 200 & 84 & 0.7913 \\
& 100 & 41 & 0.8860 \\
& 50 & 19 & 0.9437 \\
Cd(II) & 1000 & 410 & 0.3752 \\
ion & 500 & 204 & 0.5469 \\
& 200 & 77 & 0.7618 \\
\hline
\end{tabular}

adsorption on porous adsorbents may involve three steps: (1) diffusion of the ions to the external surface of adsorbent; (2) diffusion of ions into the pores of adsorbents; (3) adsorption of the ions on the internal surface of adsorbent.

\section{Conclusion}

Chitosan mixed with vermiculite has been successfully used as the adsorbent for the removal of $\mathrm{Cr}(\mathrm{VI})$ and $\mathrm{Cd}(\mathrm{II})$ from wastewater. Cadmium recovery is slightly higher at all times than chromium. The maximum adsorption for $\mathrm{Cr}(\mathrm{VI})$ has been obtained at $\mathrm{pH} 5.0$ and for $\mathrm{Cd}(\mathrm{II})$ at $\mathrm{pH}$ 5.5. The percentage of adsorption of chromium and cadmium increases steadily with solid to liquid ratio of $1-3 \%$ whereas at 4-6 saturation is attained. The adsorption of $\mathrm{Cr}(\mathrm{VI})$ and $\mathrm{Cd}(\mathrm{II})$ is found to be 59.2 and $71.5 \%$ respectively with the contact time of $300 \mathrm{~min}$. Kinetic data of adsorption studies indicate that adsorption follows pseudo second order model and bio adsorption is found to have rate limiting step. The optimum adsorption mass is $5 \mathrm{~g} /$ $100 \mathrm{ml}$ for both metals with $71.3 \%$ removal of $\mathrm{Cr}(\mathrm{VI})$ and $74.3 \%$ removal of $\mathrm{Cd}(\mathrm{II})$. The cross linker being glutaraldehyde enhances the thermal and chemical stability. Further, cross linking increases intra molecular hydrogen bonding enabling greater adsorption. The feasibility of using chitosan with vermiculite added with glutaraldehyde in the ratio $3: 1$ is established and this composition yields greater capacity for adsorption

Open Access This article is distributed under the terms of the Creative Commons Attribution 4.0 International License (http:// creativecommons.org/licenses/by/4.0/), which permits unrestricted use, distribution, and reproduction in any medium, provided you give appropriate credit to the original author(s) and the source, provide a link to the Creative Commons license, and indicate if changes were made. 


\section{References}

Ahmad AL, Kusumastuti A, Derek CJC, Ooi BS (2012) Emulsion liquid membrane for cadmium removal: studies on emulsion diameter and stability. Desalination 287:30-34

Asadi F, Shariatmadari H, Mirghaffari N (2008) Modification of rice hull and sawdust sportive characteristics for removes heavy metals from synthetic solutions and wastewater. J Hazard Mater 154:451-458

Baird C, Cann M (2005) Environment chemistry, vol 1, 3rd edn. WH Freeman and Company, San Francisco, CA, p 1555

Chang YH, Huang CF, Hsu WJ, Chang FC (2007) Removal of $\mathrm{Hg}^{2+}$ from aqueous solution using alginate gel containing chitosan. J Appl Polym Sci 104:2896-2905

Chao AC, Shyu SS, Lin YC, Mi FL (2004) Enzymatic grafting of carboxy group on to chitosan to confer on chitosan the property of a cationic dye adsorbent. Bioresour Technol 91:157-162

Chiou MS, Li HY (2003) Adsorption behavior of reactive dye in aqueous solution on chemical cross-linked chitosan beads. Chemosphere 50:1095

Chlopecka A (1996) Assessment of form of $\mathrm{Cd}, \mathrm{Zn}$ and $\mathrm{Pb}$ in contaminated calcareous and gleyed soils in Southwest Poland. Sci Total Environ 188:253-262

Chu KH (2002) Removal of copper from aqueous solution by chitosan in prawn shell: adsorption equilibrium and kinetics. J Hazard Mater B 90:77-95

Crini G (2005) Recent developments in polysaccharide-based materials used as adsorbents in wastewater treatment. Prog Polym Sci 30:38-70

Dahiya S, Tripathi RM, Hegde AG (2008) Biosorption of lead and copper from aqueous solutions by pre-treated crab and area shell biomass. Bioresour Technol 99:179-187

dos Santos ACV, Masini J (2007) Evaluating the removal of Cd(II), $\mathrm{Pb}$ (II) and $\mathrm{Cu}$ (II) from a wastewater sample of a coating industry by adsorption onto vermiculite. Appl Clay Sci 37:167-174

Du WL, Niu SS, Xu ZR, Xu YL (2009) Preparation, characterization, and adsorption properties of chitosan microspheres crosslinked by formaldehyde for copper (II) from aqueous solution. J Appl Polym Sci 111:2881-2885

Elkady MF, Abu-Saied MA, Abdel Rahman AM, Soliman EA, Elzatahry AA, ElsayedYossef M, MohyEldin MS (2011) Nanosulphonatedpoly(glycidyl methacrylate) cations exchanger for cadmium ions removal: effects of operating parameters. Desalination 279:152-162

Erosa MSD, Medina TIS, Mendoza RN, Rodriguez MA, Guibal E (2001) Cadmium sorption on chitosan sorbents: kinetic and equilibrium studies. Hydrometallurgy 61:157-167

Gerente C, Lee VKC, Lee P, McKay G (2007) Application of chitosan for the removal of metals from wastewaters by adsorption-mechanisms and models review. Crit Rev Environ Sci Technol 37:41-127. doi:10.1080/10643380600729089

Gupta VK, Ali I (2004) Removal of lead and chromium from wastewater using bagasse flyash —a sugar industry waste. J Colloid Interface Sci 271(2):321-328

Gupta VK, Nayak A (2012) Cadmium removal and recovery from aqueous solutions by novel adsorbents prepared from orange peel and $\mathrm{Fe}_{2} \mathrm{O}_{3}$ nanoparticles. Chem Eng J 180:81-90

Gupta VK, Rastogi A (2010) Biosorption of nickel onto treated alga (Oedogonium hatei): application of isotherm and kinetic models. J Colloid Interface Sci 342(2):533-539

Gupta VK, Jain R, Mittal A, Mathur M, Sikarwar S (2007) Photochemical degradation of the hazardous dye Safranin-T using $\mathrm{TiO}_{2}$ catalyst. J Colloid Interface Sci 309(2):464-469

Gupta VK, Rastogi A, Nayak A (2010) Adsorption studies on the removal of hexavalent chromium from aqueous solution using a low cost fertilizer industry waste material. J Colloid Interface Sci 342(1):135-141

Gupta VK, Agarwal S, Saleh TA (2011) Chromium removal by combining the magnetic properties of iron oxide with adsorption properties of carbon nanotubes. Water Res 45(6):2207-2212

Gupta VK, Ali I, Saleh TA, Nayak A, Agarwal S (2012) Chemical treatment technologies for wastewater recycling-an overview. RSC Adv 2:6380-6388

Hanif MA, Nadeema R, Zafar MN, Akhtar K, Bhatti HN (2007) Kinetic studies for $\mathrm{Ni}(\mathrm{II})$ adsorption from industrial wastewater by Cassia fistula (Golden Shower) biomass. J Hazard Mater 145:501-505

Ho YS, Wase DAJ, Forster CF (1996) Removal of lead ions from aqueous solution using sphagnum moss peat as adsorbent. Water SA 22:219-224

Ho YS, Huang CT, Huang HW (2002) Equilibrium sorption isotherm for metal ions on tree fern. Process Biochem 37:1421

Holm PE, Christensen TH, Tjell JC, McGrath SP (1995) Speciation of cadmium and zinc with application to soil solutions. J Environ Qual 24:183-190

Holme KR, Perlin AS (1997) Chitosan N-sulfate. A water-soluble polyelectrolyte. Carbohydr Res 302:7-12

Horsfall MJ, Spiff AI (2005) Sorption of lead, cadmium and zinc on sulfur-containing chemically modified wastes of fluted pumpkin. Chem Biodivers 2:373-385

Jain AK, Gupta VK, Bhatnagar A, Suhas (2003) A comparative study of adsorbents prepared from industrial wastes for removal of dyes. Sep Sci Technol 38(2):463-481

Jayakumar R, Rajkumar M, Freitas H, Selvamurugan N, Nair SV, Furuike TH, Tamura H (2009) Preparation, characterization, bioactive and metal uptake studies of alginate/phosphorylated chitin blend films. Int J Biol Macromol 44:107-111

Li Q, Zhai J, Zhang M, Wang J, Zhou J (2007) Kinetic studies of adsorption of $\mathrm{Pb}$ (II), $\mathrm{Cr}(\mathrm{III})$ and $\mathrm{Cu}(\mathrm{II})$ from aqueous solution by sawdust and modified peanut husk. J Hazard Mater 141:163-167

Malandrino M, Abollino O, Giacomino A, Aceto M, Mentasti E (2006) Adsorption of heavy metals on vermiculite: influence of pH and organic ligands. J Colloid Interface Sci 299:537-546

McBride M (1994) Environment chemistry of soils. Oxford University Press, New York

Mittal A, Gipta VK, Malviya A, Mittal J (2008) Process development for the batch and bulk removal and recovery of a hazardous, water-soluble azo dye (Metanil Yellow) by adsorption over waste materials (Bottom Ash and De-Oiled Soya). J Hazard Mater 151(2-3):821-832

Mittal A, Mittal J, Malviya A, Kaur D, Gipta VK (2010) Adsorption of hazardous dye crystal violet from wastewater by waste materials. J Colloid Interface Sci 343(2):463-473

Morimoto M, Saimoto H, Shigemasa Y (2002) Control of functions of chitin and chitosan by chemical modifications. Trends Glycosci Glycotechnol 14:205-222

Ngah WSW, Hanafiah MAKM (2008) Biosorption of copper ions from dilute aqueous solutions on base treated rubber (Hevea brasiliensis) leaves powder: kinetics, isotherm, and biosorption mechanism. J Environ Sci 20:1168-1176

Ngah WSW, Kamari A, Koay YJ (2004) Equilibrium and kinetic studies of adsorption of copper(II) on chitosan and chitosan/PVA beads. Int J Biol Macromol 3:155-161

Ofomoja AE, Ho YS (2006) Equilibrium sorption of anionic dye from aqueous by palm kernel fibre as sorbent. Dyes Pigments 12:249-257

Popuri SR, Vijaya Y, Boddu VM, Abburi K (2009) Adsorptive removal of copper and nickel ions from water using chitosan coated PVC beads. Bioresour Technol 100:194-199

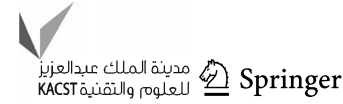


Prakash N, Sudha PN, Renganathan NG (2011) Copper and cadmium removal from synthetic industrial wastewater using chitosan and nylon 6. Environ Sci Pollut Res 19(7):2930-2941

Prakash N, Latha S, Sudha PN, Renganathan NG (2012) Influence of clay on the adsorption of heavy metals like copper and cadmium on chitosan. Environ Sci Pollut Res 20(2):925-938

Saeed A, Iqbal M (2003) Bioremoval of cadmium from aqueous solution by black gram husk (Cicer arientinum). Water Resour 37(14):3472-3480

Srivastava SK, Gupta VK, Mohan Dinesh (1997) Removal of lead and chromium by activated slag-a blast-furnace waste. J Environ Eng 123(5):46-468

Takiguchi M, Yoshihara S (2006) New aspects of cadmium as endocrine disruptor. Environ Sci 13(2):107-116
Tao Y, Ye L, Pan J, Wang Y, Tang B (2009) Removal of Pb(II) from aqueous solution on chitosan/ $/ \mathrm{TiO}_{2}$ hybrid film. J Hazard Mater 161:718-722

Vasudevan S, Lakshmi J, Sozhan G (2011) Effects of alternating and direct current in electrocoagulation process on the removal of cadmium from water. J Hazard Mater 192:26-34

Wang JW, Kuo YM (2008) Preparation and adsorption properties of chitosan-poly (acrylic acid) nanoparticles for the removal of nickel ions. J Appl Polym Sci 07:2333-2342

Wankasi D, Horsfall HJ, Spiff AI (2006) Sorption kinetics of $\mathrm{Pb}^{2+}$ and $\mathrm{Cu}^{2+}$ ions from aqueous solution by Nipah palm (Nypa fruticans Wurmb) shoot biomass. Electron J Biotechnol 9:587-592

Xu X, Li L, He J (2009) The performances of carboxymethyl chitosan in wash-off reactive dyeing. Carbohydr Polym 75:203-207 